\title{
How is the Compensation of Employees?
}

\author{
Elfira Fawzia ${ }^{1}$, Firman Pribadi ${ }^{2}$ \\ ${ }^{1,2}$ Universitas Muhammadiyah Surakarta, Indonesia \\ *Correspondence email: elfira.fauzia.pcs19@mail.umy.ac.id
}

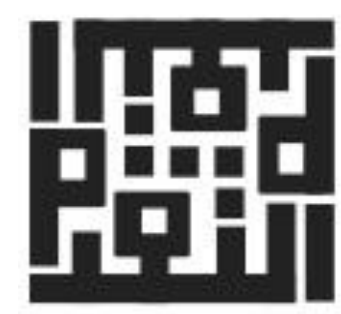

ISSN: 1979-4703 (p)

ISSN: 2527-9726 (e)

\section{Article history:}

Received 30 April 2021

Accepted 30 May 2021

Published 30 June 2021

\section{Keywords:}

Compensation;

Employees; Hospital

\section{Introduction}

The hospital is a health service institution for the community with high capital, human resources (HR), and science \& technology. It should be able to manage these factors to carry out business according to its objectives. All human resources have the same duty and role in ensuring the quality of health services, starting from staff, nurses, doctors, and all stakeholders. Therefore, they all get the right to the obligations carried out in the form of remuneration (Soetisna, Ayuningtyas, and Misnaniarti 2015), (Dakota et al. 2017).

Each hospital should provide compensation to employees according to applicable procedures. The legal basis for hospital remuneration refers to three regulations, namely Law Number 44 of 2009 concerning Hospitals, Regulation of the Minister of Health Number 63 of 2016 concerning guidelines for the financial management of Public Service Bodies within the Ministry of Health, and 
regulation of the minister of finance of the Republic of Indonesia number 176 / PMK. 05/2017 regarding the remuneration guidelines for Public Service Bodies.

The provision of compensation or remuneration in the hospital is included in the human resource management division (HRM). Therefore, there is a relationship with other parts that influence Each other to a specific goal to compile a remuneration system (Hidayah 2017). In improving performance, restitution should be commensurate, fair, and appropriate according to the hospital's financial capacity. Buchan et al. stated that remuneration takes a strategic portion in the hospital as a performance boost and evaluates efficient and effective health services (Ekdahl 2014).

Hospitals should design and decide on a remuneration method according to the rules without neglecting their financial strength. Referring to Law (UU) Number 44 of 2009) regarding hospitals, Article 30 emphasizes that non-governmental hospitals can adopt a remuneration system that already has guidelines by making adjustments to suit the hospital's conditions and interests or design a remuneration system. Remuneration needs to be carried out accurately, openly, under one's responsibilities, and wisely because the impact has a significant impact (for example, dislike, distrust of each other, prejudice, and disappointment). More than that, it can result in decreased performance, the work environment is not conducive, and can lead to distrust (Darmawan 2008).

Although many hospital management have attended training and understand the descriptions and procedures, they have not been able to apply the system because of their daily work routines (Hidayah, 2017). Therefore, a joint commitment from the hospital management is needed because compiling and creating a remuneration system requires intensive efforts, participation in all parties, and separate funding allocations. Previous studies on remuneration systems analyzed the relationship between hospital remuneration and performance, such as (Apriliani and Hidayah 2020), (Hartati, Rima Semiarty 2019), (Rauf and Syarifuddin 2019), (Dakota et al. 2017), (Malwa 2016), (Puspita, Sukarsa, and Sudana 2015), (Soetisna, Ayuningtyas, and Misnaniarti 2015), (Darmawan 2008), (Tasneem et al. 2018), (Yani et al. 2018), (Zhang and Liu 2018), (Husna 2020), (Yan, Yu-Hua Kung 2017), (Onuoha 2017), (Mendes et al. 2017). In addition, other research on hospital remuneration design has also been conducted (Hendryani 2017) (Nia Budi Puspitasari 2016).

There have not been many studies on remuneration in hospitals as has been done by (Nur Hidayah 2018). So, that there is a research gap that must be filled in this gap. The purpose of this study was to analyze the remuneration of permanent employees at PKU Aisyiyah Jepara Hospital. PKU Aisyiyah Jepara Hospital is a Muhammadiyah Business Charity (AUM) in Jepara. This research is essential for several considerations. There is no remuneration system for permanent employees at PKU Aisyiyah Jepara Hospital, so a benchmarking model is needed from theory and similar and closest hospitals such as Aisyiyah Kudus Hospital and Fastabiq Sehat PKU Muhammadiyah Pati Hospital. According to the Law 
mandate regarding hospitals, article 30 states that all remuneration forms are adjusted to the regulations. The system for determining nursing services incentives is not under the law so that there is no proportional reward.

\section{Literature Review}

Previous research is used to build a theoretical framework so that a clear description of the flow of this research can be seen. For example, previous research has discussed the correlation of remuneration on the performance of hospital employees, such as Apriliani and Hidayah (2020). Who investigated the relationship between remuneration, motivation, and job satisfaction of nurses at PKU Muhammadiyah Gamping Hospital for June 2020 with 123 samples of nurses in three of 8 wards, namely, inpatient wards. Inpatient, ICU, and ICCU rooms. The questionnaire was used as a data collection instrument to obtain the findings of the relationship between research variables. The study results partially show that remuneration has a positive and significant relationship to motivation and job satisfaction.

Meanwhile, the simultaneous test shows a direct relationship between remuneration and job satisfaction of nurses, which is greater than the indirect effect. These findings suggest optimization of ward service motivation and job satisfaction through remuneration adjustments. This finding is different from Soetisna, Ayuningtyas, and Misnaniarti (2015), who stated dissatisfaction with implementing the remuneration system.

Hartati, Semiarty, and Verinita (2019) conducted a study on the effect of remuneration and work environment on the performance of specialist doctors with the mediating variable of work motivation in a Padang Hospital. This research approach uses explanatory with a sample of 36 obstetricians and pediatricians. To test the research variables using the Partial Least Square (PLS) technique. As a result, there is no relationship between remuneration, work environment, and work motivation on performanceresearch conducted by Rauf and Syarifuddin (2019) on remuneration on employee performance in a surgical hospital. The number of research samples amounted to 50 employees with purposive sampling. Questionnaires were used as data collection with simple linear regression analysis. Partially, the results show that there is a positive correlation between remuneration and employee motivation. Interestingly, it is supported by good relations between employees. This finding is strongly supported by research by Malwa (2016), which states that remuneration can improve employee performance.

To analyze the effect of compensation on career development, job satisfaction, and intention to switch nurses in private hospitals in Yogyakarta (Hidayah and Ananda: 2018). A quantitative research design with cross-sectional is used. Furthermore, the selected simple random sampling amounted to 47 nurses who made their reports by filling out a questionnaire. Technik analysis data using Partial Least Square. This study found that career development has a significant effect on job satisfaction and turnover intention. However, compensation does not impact job satisfaction and turnover intention. Likewise, job satisfaction also does not affect turnover intention. The implication 
is that hospitals must improve the career development of nurses to reduce turnover intentions. To support the remuneration policy it is necessary to integrate a good management information system. Puspita, Sukarsa, and Sudana (2015) researched designing a personnel data system to provide convenience to the management as a guide in the remuneration process using the Total Architecture Synthesis method. As a result, these findings are in the form of modules to be used as management guidelines, in contrast to Hendryani (2017), who conducted research using the Framework for the Application of System Thinking method to develop a remuneration scheme for services at the Kepahiang Hospital. As a result, the FAST system has more effective performance.

Darmawan's research (2008) analyzed determining nurse service incentives at RSUD dr. H. Soewondo Kendal. The research instrument used in-depth interviews, benchmarking, and Focus Group Discussions to obtain the elements of determining incentives. The finding is that there is a disproportionate amount of incentive for nurses. The incentives should be set according to the health regulation. The results of studies in other countries, such as those conducted by Tasneem et al. (2018) This particular study was conducted to assess the job satisfaction of healthcare employees in a public tertiary hospital to identify various underlying factors. Data were collected using Job Satisfaction Survey (JSS) questionnaire \& analyzed using SPSS 18. The results showed that most employees were satisfied with their boss, nature of work, and co-workers but were dissatisfied with other factors such as salary, benefits, communication, and on- site conditions. This finding is supported by Johari (2014), who stated that the performance of medical staff and the quality of medical services in government hospitals in Libya.

Yani et al. (2018) aim to identify the effect of the remuneration system on nurse performance. The study design used a literature review and involved analysis of 25 articles published in the Cumulative Index to Nursing and Allied Health Literature (CINAHL), MEDLINE, EMBASE, PsycINFO, and the Global Health database. The literature is limited to articles published in English between August 2006 and August 2015. This study indicates that improving the remuneration system has positive consequences in terms of nurse performance and subsequent quality of health care. A well-managed remuneration system can increase motivation, productivity, nurse satisfaction, and even increase retention. On the other hand, poorly managed and low remuneration contributes to the shortage of nurses due to the high turnover rate.

Zhang and Liu (2018) investigated the factors that determine the workload and salary of doctors in China. This type of research includes a national survey involving 136 hospitals in 31 provinces with a sample of 17,615 doctors in 2015 . Univariate analysis and general estimation equations to evaluate factors related to salary. As a result, in 2015, the median annual salary of physicians was US $\$ 13,764$. Doctors in eastern China earned more than those in central $(p<0.001)$ and western China $(p=0.002)$ after adjusting for local per capita expenditure. Salaries for men in 2015 were US $\$ 14,832$, which is more than 
that for women (US\$12,912; $\mathrm{p}<0.001)$. Of the respondents, $76.3 \%$ work more than 40 hours per week. Doctors treat an average of 40 patients per day. As a result, $67.2 \%$ of physicians spent no more than 10 minutes with each outpatient. After adjustment for age and management position, the salary was associated with years in practice, educational background, and specialization, but not with weekly hours worked and gender.

Yan, Yu-Hua Kung (2017) tried to compare private and non-profit hospitals regarding the relationship between hospital image and compensation/benefit systems on organizational attractiveness. The questionnaire survey method was adopted in this study, with employees from two hospitals as applicants. 1,138 valid questionnaires underwent Pearson correlation analysis and multiple regression analysis. Onuoha's research (2017) investigates the factors that can motivate nurses in Trinidad and Tobago. This type of research uses a cross-sectional descriptive design. The population came from four main hospitals selected in the island nation using an instrument adapted from the Human Resource Management Foundation (SHRM), Employee Engagement Survey Template Software (2014). The results showed that nurses in Trinidad and Tobago came from various ethnicities, primarily women, had different occupational statuses. They also showed that nurses' motivation/satisfaction was not related to their gender and their age. The results found that ethnicity, occupational institutions, education level, and employment status, among others, were significantly related to several motivational factors for nurses in Trinidad and Tobago.
It is different from Dakota et al. (2017) research, which analyzes the implementation of remuneration policies in government hospitals in Jakarta. The number of samples is ten medical personnel with in-depth interview instruments. The findings of this study indicate that the remuneration policy is quite appropriate to be implemented in the research object hospital. It's just that several aspects must be consideredresearch recommendations for hospitals to carry out continuous evaluation and monitoring of remuneration policies with all stakeholders. Mendes et al. (2017) conducted a study to analyze employee perceptions of the remuneration system in two main hospitals in Brazil, one managed by the government and one private. The number of samples was 109 respondents from 54 private hospitals and 55 government hospitals. The results show that fixed salary is different for employees in the two fields and concerning public and private hospital management.

Research Mendelson et al. (2017) investigated the effects of pay-forperformance at the physician, group, managerial, or institutional level on care processes and patient outcomes in outpatient and inpatient settings. Data were obtained from PubMed from June 2007 to October 2016; MEDLINE, PsycINFO, CINAHL, Economics, and Business Theory, Elite Business Resources, Scopus, Faculty 1000, and Gartner Research from June 2007 to February 2016. As a result, pay-for-performance programs can improve the care process, but we found no clear evidence to demonstrate that they improve patient outcomes. 
In contrast to previous studies, this study will examine the calculation of the remuneration of permanent employees at PKU Aisyiyah Hospital Jepara, which refers to the Minister of Health Number 176 / PMK.05/2017 and Number 63 of 2016. The indicators taken from the Minister of Health in this study have two factors: proportionality, equity, propriety, and operational performance, secondly Pay for position, Pay for performance, and Pay for people. This indicator is considered to be more able to describe the level of remuneration information expected by stakeholders. In addition, this study focuses on calculating remuneration in hospitals, so it is unique considering that most previous studies have focused on the relationship of remuneration to performance and how the information system is built and developed.

\section{Research Method}

The action research based on a qualitative case study uses purposive sampling involving nine directly involved in the compensation process: three directors, three heads of general and finance department, and three financial staff. The remuneration variable refers to the basic principles of remuneration, including proportionality, equality, appropriateness BLU operational performance, and remuneration components including Pay for position, Pay for performance, and Pay for people. The data analysis technique used qualitative analysis, where the results did not show statistics. So that the steps taken collect data, display data, data reduction, and conclusion

\section{Result and Discussion}

Based on the 2015 presidential regulation concerning guidelines for hospital organization, article 6 states that the hospital organization consists of at least the head of the hospital or the director of the hospital; elements of medical services; nursing elements; medical support elements; elements of general and financial administration; medical committee; and internal inspection units (2015 2015).

The remuneration system regulations for managing officials and employees at 'Aisyiyah Kudus Hospital with number 155 / SK-PDA / E-RS / IX / 2017. The interviews with the President Director of the Hospital' Aisyiyah PKU Jepara and Deputy director of general and operation of the hospital' Aisyiyah Suci that the level of rank implemented is under the terminology listed in the Decree of the Position. This is under what was stated by the Director of General Affairs and Operations of 'Aisyiyah Kudus Hospital, dr. Hendra Octavianto as follows:

"Well ... In our' Aisyiyah Kudus hospital,
there are two groups ... structural and non-
structural groups. This structure consists of
the Director, Deputy Director, Manager,
and Head of Unit. Then the non-structural
ones are the head of the internal supervisory
unit and the committee chairman, like
that".

Not much different from the Hospital' Aisyiyah Kudus, PKU Aisyiyah Jepara Hospital, where the types of management organizations are structural and nonstructural as disclosed:

"In our hospital, structural types include
Director, Head of general and finance 
department, Head of the service department, and Head of the unit. Meanwbile, the nonstructural ones consist of the Head of the SPI and the Chair of the Committee".

It is different from the Fastabiq Sehat PKU Muhammadiyah Pati Public Hospital's organizational structure, which already has many fields. This is because the size of the hospital has many services. Under the findings of an interview with Dr. Aldila $S$ Al Arfah as the President Director who stated:

"Structurally, the structure in our hospital, Directors, Managers, Supervisors, Head of Installation, Head of Room, IPCN, Case Manager, PMKP Secretary, Team Leader, Committee Chair, Staff, On Duty Leader and Coordinator. Meanwhile, the nonstructural ones are Implementers (Clinical Nurses, Medical Supporters, General Administrators (General Rank), medical staff".

One of the hospital management must carry out elements is to determine remuneration, fill in the position questionnaire form according to corporate grade, and review and assess positions based on the Remuneration Advisory Team at the Directorate General Health Efforts, Ministry of Health RI. The interview results illustrate that it is under the Directorate General of Health Efforts in determining remuneration, the process of filling in the job questionnaire forms and reviewing and assessing according to corporate grade. As disclosed by $\mathrm{dr}$. Hendra Octavianto Deputy Director General and Operations' Aisyiyah Kudus Hospital:

"Not yet, the Aisyirah Hospital has not adhered to the Remuneration Advisory Team of the Directorate General of Health
Efforts at the Ministry of Health of the Republic of Indonesia. Therefore, filling in the e form is adjusted to the corporate-grade position, competence, and performance. Furthermore, for the process of reviewing and assessing the position, we analyze the job descriptions, and job requirements, job responsibilities, targets, and business acbievements".

The next stage is grouping positions based on corporate-grade levels. Technically, each hospital has almost the same method because it follows the Remuneration Advisory Team's flow for the Directorate General of Health Efforts of the Ministry of Health of the Republic of Indonesia. Dr conveyed the same thing. Hendra Octavianto Deputy Director General and Operations' Aisyiyah Kudus Hospital:

"First, we review the organization as a whole and, according to each position, determine how the job analysis information, select positions to be analyzed, collect data with certain analyzes, then prepare job specifications, like that ma'am.... While technically, we first set a corporate grade. We analyzed the job by evaluating the value, the job, the rank of position, looking at the composition and number of employees ".

Meanwhile, the results of interviews with PKU Aisyiyah Jepara Hospital regarding remuneration determination, filling in the position questionnaire forms according to corporate-grade, and reviewing and assessing positions revealed:

"The stages of the regulation of the Directorate General of Health Efforts' Guidance Team of the Ministry of Health of the Republic of Indonesia are the identification according to the Organizational and Governance Units, 
filling out a job questionnaire, analyring positions and grouping positions. Meanwhile, PKU Aisyiyah Jepara Hospital is under its stages, but filling the position questionnaire is carried out by granting SOPs containing authorities, responsibilities, and duties. Meanwhile, the process of filling out questionnaire forms according to a position based on corporategrade, competence, workload, and responsibility".

Unlike before, PKU Muhammadiyah's PKU healthy Fastabiq Hospital has not carried out the remuneration and position grouping stages under the Remuneration Advisory Team of the Directorate General of Health regulations Efforts at the Ministry of Health Republic of Indonesia. However, in the process of reviewing and assessing positions based on statutory regulations. This was expressed by Dr. Aldila S Al Arfah as the President Director as follows:

"Not yet, based on reference No. 10 / PMK.02 / 2006 jo. PMK No. 73/PMK.05/2007, concerning Guidelines for Determining Remuneration for Management Officials, Dewas, and $B L U$ Employees and remuneration workshop material delivered by $D r$. Suranto MM." Currently, we are still in the process of perfecting the grouping of Doc's positions, the target is that in 2021 the system will be running well".

The hospital takes several principles into account in providing remuneration according to rank and proficiency, including proportionality, equality, appropriateness, and performance. The proportionality principle considers aspects of capital, income, human resources, and BLU services. The research findings show that 'Aisyiyah PKU Kudus Hospital has implemented four principles of giving remuneration. Also, the hospital has various types of services. Dr. Hendra Octavianto, Deputy Director for General Affairs and Operations at 'Aisyiyah PKU Kudus Hospital, as follows:

"For proportionality, our total assets are 35 billion, and annual revenue is around 80 billion with 370 employees. Furthermore, there are several services, namely outpatient care, inpatient care, emergency unit, intensive care, medical support, laboratory, radiology, pharmacy, vision, and hemodialysis unit".

Meanwhile, PKU Aisyiyah Hospital, Jepara, has a system of analysis and assessment of positions as well as medical services in proportional aspects as disclosed:

"In our hospital, currently, the total asset is only 8 billion with an annual income of 3 billion, which 61 employees support. We serve outpatient care, inpatient care, emergency care, intensive care, medical support, laboratory, radiology, pharmacy, and nutrition".

Meanwhile, at the PKU Muhammadiyah Fastabiq Sehat Hospital, based on the proportionality aspect, it shows the same thing as expressed by Dr. Aldila S Al Arfah as the President Director as follows:

"Our hospital data shows total assets of 53 billion, the revenue of 4.4 billion, with 350 employees. Our hospital offers services including; outpatient, Obsgyn, Internal, Child, General Polyclinic, Nerve, Dental, Lung, Surgery, Dental \& Oral, ENT, Cardiac, Hemodialysis, Urology, Psychology, Inpatient, IGD, IBS, VK, ICU, and supporting services such as 
Laboratory,

Physiotherapy".

Pharmacy, and

Furthermore, the principle of equality is to compare remuneration with similar services. This study's findings indicate that 'Aisyiyah PKU Kudus Hospital has implemented this principle by benchmarking other hospitals in similar services to determine remuneration. As stated by dr. Hendra Octavianto Deputy Director for General Affairs and Operations at 'Aisyiyah PKU Kudus Hospital:

"Yes, we are doing benchmarking with our network. The need for networking is in..., namely the Mubammadiyah Hospital and the 'Aisyiyah Hospital.'

PKU Aisyiyah Jepara Hospital regarding equality did the same thing by benchmarking other hospitals to determine remuneration as disclosed: "Yes, with other RSM." On the other hand, the PKU Muhammadiyah Fastabiq Sehat Hospital on equality illustrates no benchmarking in determining remuneration for similar services to other hospitals. However, in the aspect of appropriateness in determining remuneration, it has been adjusted to the capacity of the hospital as expressed by Dr. Aldila S Al Arfah as the President Director:

"We bave not implemented this aspect, but for the aspect of appropriateness, the remuneration for all employees is in line with the financial capacity of the hospital."

The next principle is appropriateness, in which the determination of remuneration takes into account rank levels according to the results of analysis and evaluation. According to this context, does the hospital provide remuneration under the financial capacity of the hospital? These findings indicate that the determination of remuneration has referred to the principle of appropriateness as expressed by $\mathrm{dr}$. Hendra Octavianto Deputy Director for General Affairs and Operations at 'Aisyiyah PKU Kudus Hospital:

"Yes, um ... we determine remuneration according to financial capacity, that is, we always assess the hospital cash flow from year to year, and we adjust the increase according to service improvements, if service increases, income increases, then ee remuneration will automatically increase, according to income, We will improve employee welfare".

Both RS PKU Aisyiyah Jepara and Fastabiq Sehat PKU Muhammadiyah in terms of the principle of fairness have the same as providing remuneration according to the hospital's financial capacity as expressed by Dr. Aldila S Al Arfah as the President Director:

\section{"Yes, according to the ability of the hospital."}

There are three main systems in implementing remuneration that serve as guidelines for hospitals, including Pay for the position, Pay for performance, and Pay for people. As feedback on the implementation of P1-P3, a survey of employees is required to assess their remuneration satisfaction. The findings showed that $\mathrm{dr}$ stated the implementation of remuneration. Hendra Octavianto Deputy Director of General Affairs and Operations at PKU Kudus' Aisyiyah Hospital, namely:

"Yes, we have implemented all three, namely pay forposition based on the payroll of civil servants (PGPNS) 2015 of 100\%, 
then pay for performance is based on performance, namely in the form of functional allowances. In comparison, the implementation of Pay for people is implementing BPJS premium subsidies for bealth and employment for all employees, intensive provision, and SHU, based on the level of individual attendance and the level of discipline in the reading program Quran letters and meanings (BASOPATI). After implementing eee what... basic salary of 100\% PGPNS 2015 we conducted a satisfaction survey, and the results were $75 \%$ satisfied with the application.

Meanwhile, PKU Aisyiyah Hospital Jepara implements a remuneration system based on P1-P3 as explained:

"For our hospital, Pay for the position is based on the lowest salary of GP PNS 2000, each goal increase increases by 10\%. Pay for performance is based on the level of performance achievement and functional allowances. Pay for people in BPJS Health insurance premium subsidies, incentives, and severance pay according to SDI regulations approved by the Jepara District Manpower Office. Furthermore, based on performance through KPI and IKU, we measure performance achievement and functional allowances. Alhamdulillah, the response from permanent employees is 50\% not concerned with their salary, it's just that our hospital has not conducted a satisfaction survey".

At the PKU Muhammadiyah Fastabiq Sehat hospital, the implementation of the Pay for the position, Pay for performance, and Pay for people remuneration system shows something different from the findings at the previous hospital as expressed by Dr. Aldila S Al Arfah as the President Director:

"Currently, it is still in the process of
improving the system and regulations. In
the current system, the base salary is
calculated at $75 \%$ of the MSE. For each
additional one-year working period, the
base salary increases by 20,000.
Performance is included in the KPI
assessment (key performance indicator),
which is assessed every month. KPI consists
of the main KPI (related to employee
productivity/job description) and Basic
KPI (related to the value of data and
individual development, a.l discipline,
recitation, tidiness, congregational prayer,
etc.). Bonuses or incentives are given based
on the hospital's productivity. If the ratio of
HR costs: Turnover is less than $20 \%$, the
difference will be shared in the form of
bonuses (mutual incentives). Details of
satisfaction can be checked in the
recapitulation we sent yesterday, Doc".

As the results of interviews that researchers on aspects of P1-P3 have conducted are not explained in detail, the calculation method follows the provisions, even though all components are under ministerial regulation of the Republic of Indonesia 2017. For example, P1 is calculated to be a maximum of $30 \%$ Job Value $x$ PIR), P2 is calculated from the IKI. $\mathrm{X}$ IKU X 70\% for services and P3 is calculated from $10-15 \%$ of the remuneration budget allocation. This means that the study results showed no significant difference in the method of providing incentives for PKU Aisyiyah Jepara Hospital with the benchmarking hospital. However, there are similar findings, namely employee satisfaction with the remuneration that all hospitals 
have implemented. These findings are in line with (Brien 1998; Dakota et al. 2017; Darmawan 2008; Hartati, Rima Semiarty 2019; Malwa 2016; Nur Hidayah 2018; Ramzan et al. 2014; Said Muhammad Rauf and Syarifuddin 2019).

\section{Conclusions}

Based on the research objectives, it can be concluded that the findings indicate that the method formulated in providing service incentives at PKU Aisyiyah Jepara Hospital is under the regulation of the minister of the Republic of Indonesia in 2017. However, the calculations are not explained in detail. In addition, benchmarking with other hospitals, there is not much difference in providing service incentives at PKU Aisyiyah Jepara Hospital.

\section{Recommendation}

Therefore, future research is expected to take more complete results from central or local government hospital benchmarking.

\section{References}

Apriliani, Elmira, and Nur Hidayah. 2020. 'Hubungan Remunerasi Dan Motivasi Kerja Dengan Kepuasan Kerja Perawat Di RS PKU Muhammadiyah Gamping'. Jurnal Ilmiah Universitas Batanghari Jambi 20, no. 1 : 137. https://doi.org/10.33087/jiubj.v20i1 .777 .

Brien, Rory O. 1998. An Overview of the Methodological Approach of Action Research.

Dakota, Iwan, Dumilah Ayuningtyas, Ratih Oktarina, and Misnaniarti
Misnaniarti. 2017. 'Implementasi Kebijakan Remunerasi Di Rumah Sakit Pemerintah'. Jurnal Kebijakan Kesehatan Indonesia 6, no. 3: 159. https://doi.org/10.22146/jkki.v6i3.2 9669.

Darmawan, R. Ibnu. 2008. Analisis Penetapan Insentif Pelayanan Tenaga Perawat Di RSUD Dr. H. Soewondo Kendal.

Ekdahl, A. W. 2014. 'The Organisation of Hospitals and the Remuneration Systems Are Not Adapted to Frail Old Patients Giving Them Bad Quality of Care and the Staff Feelings of Guilt and Frustration'. European Geriatric Medicine 5, no. 1: 35-38. https://doi.org/10.1016/j.eurger.201 3.10.002.

Hartati, Rima Semiarty, Verinita. 2019. 'Analisis Dampak Remunerasi Dan Lingkungan Kerja Terhadap Kinerja Dokter Spesialis Dengan Motivasi Kerja Sebagai Variabel Mediasi'. Jurnal Imiah Manajemen 8, no. 1: 12534.

Hendryani, Atika. 2017. 'Rancang Bangun Sistem Informasi Remunerasi Jasa Pelayanan RSUD Kepahiang Bengkulu Menggunakan Metode FAST'. Jurnal Sistem Informasi Bisnis 7 , no. 1 : 9. https://doi.org/10.21456/vol7iss1p p9-16.

Hidayah, Nur. 2017. Sebagai Strategi Manajemen Sumber Daya Manusia Di Rumah Sakit.

Husna, Fathayatul. 2020. 'Wajah Ekonomi 4.0: Perbankan Syari'ah Digital, Peningkatan Daya Saing Dan Strategi Dakwah Islam'. Idaratuna: Jurnal 
Kajian Manajemen Dakwah 21, no. 1: 59-70.

https://doi.org/1010.24014/idarotu na.v3i1.Wajah.

Malwa, Juairiah dan Rosyidah Umpu. 2016. 'Hubungan Antara Pemberian Remunerasi Terhadap Kinerja Karyawan Di Rumah Sakit Islam Siti Khadijah Palembang'. PSIKIS-Jurnal Psikologi Islami 2, no. 2: 161-71. https://doi.org/10.1017/CBO97811 07415324.004 .

Mendes, Alcindo, Rogério João Lunkes, Leonardo Flach, and Silvana Dalmutt Kruger. 2017. 'The Influence of Remuneration on the Behavior of Hospital Employees in Brazil'. Contaduría y Administración 62, no. 1: 207-21.

https://doi.org/10.1016/j.cya.2016.0 4.005 .

Nia Budi Puspitasari, Meisarah Sabrina Arifianty. 2016. 'Pengaruh Kualitas Pelayanan Terhadap Kepuasan Pasien'. In Prosiding SNST Ke-7 Tabun 2016, 1:1. https://doi.org/10.21070/jkmp.v1i1 .429 .

Nur Hidayah, Arlina Dewi dan Ekorini. 2018. 'Model Sistem Remunerasi Sebagai Strategi Peningkatan Mutu, Efektivitas Biaya, Outcome Rumah Sakit Amal Usaha Muhammadiyah'.

Onuoha, Philip. 2017. 'Factors That Contribute to Work Motivation and Job Satisfaction among Hospital Nurses in Trinidad and Tobago International Journal of Health Sciences and Research Factors That Contribute to Work Motivation and Job Satisfaction among Hospital
Nurses in Tri', no. August.

PERPRES RI. 2015. Perpres RI Nomor 77 Tabun 2015. Vol. 151.

Puspita, A A Primaningrat Gita, I Made Sukarsa, and A A K Oka Sudana. 2015. 'Perancangan SIMRS Terintegrasi Modul Human Resource Development Pada Rumah Sakit Pendidikan'. Lontar Komputer 6, no. 1: 37-48.

Ramzan, Muhammad, Hafiz M Kashif Zubair, Ghazanfar Ali, and Muhammad Arslan. 2014. 'Impact of Compensation on Employee Performance ( Empirical Evidence from Banking Sector of Pakistan ) Islamia University of Bahawalpur Research Scholars of Department of Management Sciences'. International Journal of Business and Social Science 5, no. 2: 302-9.

Said Muhammad Rauf dan Syarifuddin. 2019. 'Pengaruh Remunerasi Terhadap Kinerja Karyawan Halmahera Group Di Rumah Sakit Khusus Bedah Halmahera Siaga'. In Proceeding of Management, 6:4488-93.

Soetisna, Tri Wisesa, Dumilah Ayuningtyas, and Misnaniarti. 2015. 'Penerapan Sistem Remunerasi Dan Kinerja Pelayanan Implementation of Remuneration System and Service Performance'. Jurnal Kesehatan Masyarakat Nasional 10, no. 1: 17-23.

Tasneem, Saima, Ayse Seyer Cagatan, Mehmet Zeki Avci, and Ahmet Celal Basustaoglu. 2018. 'Job Satisfaction of Health Service Providers Working in a Public Tertiary Care Job Satisfaction of Health Service 
Providers Working in a Public Tertiary Care Hospital of Pakistan'. The Open Public Health Journal Content 11, no. May: 17-27. https://doi.org/10.2174/187494450 1811010017.

Yan, Yu-Hua Kung, Chih-Ming. 2017. 'Hospital Image and Compensation/Benefit System on Organizational Attractiveness'. Public Health - Open Journal 2, no. 1: 33-41. https://doi.org/10.17140/phoj-2-
118.

Yani, Achir, Syuhaimie Hamid, Rr Tutik, and Sri Hariyati. 2018. 'Improving Nurses' Performance through Remuneration: A Literature Review'. Enfermería Clínica 28, no. 1: 130-33.

Zhang, Chunyu, and Yuanli Liu. 2018. 'The Salary of Physicians in Chinese Public Tertiary Hospitals : A National CrossSectional and Follow-up Study'. BMC Health Services Research 18: 1-9. 